\title{
A Methodology for Experimental Research of the Freezing Process of Logs
}

\author{
Nencho DELIISKI ${ }^{*}$ - Natalia TUMBARKOVA \\ Department of Woodworking Machines, Faculty of Forest Industry, University of Forestry, Sofia, Bulgaria
}

\begin{abstract}
This paper describes a methodology for experimental research of the change in the temperature and humidity of the air processing medium and also in the temperature at 4 points of the longitudinal section of logs during freezing. The suggested methodology is used to research the change in the mentioned parameters of poplar logs with diameters of $240 \mathrm{~mm}$, lengths of $480 \mathrm{~mm}$ and moisture content above the hygroscopic range during $50 \mathrm{~h}$ of freezing in a freezer at a temperature of about $-30{ }^{\circ} \mathrm{C}$. The automatic measurement and recording of the parameters is carried out with the help of Data Logger type HygrologNT3 produced by the Swiss firm ROTRONIC. The precise instrumentation allowed, for the first time ever, the measuring of the impact the latent heat released by the free water on the log had on the warming up of the wood during water crystallization in the logs.
\end{abstract}

poplar logs / freezing / temperature distribution / automatic measurement / latent heat

Kivonat - Rönkfagyasztás kísérleti kutatásának módszere. Ez a cikk leírja a h mérséklet és a nedvességtartalom változását leveg ben elhelyezett rönk fagyasztásakor, és mutatja a $\mathrm{h}$ mérsékletet hosszirányban lév 4 különböz pontban. A javasolt módszert használtuk, hogy megvizsgáljuk a fenti paraméterek változását $240 \mathrm{~mm}$ átmér j , $480 \mathrm{~mm}$ hosszú, nedves állapotú nyár rönkök fagyasztási vizsgálatainál $-30{ }^{\circ} \mathrm{C}$ körüli h mérsékleten, 50 órás id tartamon. A paraméterek automatikus mérése és rögzítése a svájci ROTRONIC cég által gyártott HygrologNT3 eszközzel történt. A pontos mér rendszerrel, els alkalommal sikerült megmérni a megfagyó víz által kibocsátott látens h nek a faanyagot felmelegít hatását.

nyár rönkök / fagyasztás / h mérséklet eloszlás / automatikus mérés / latens h

\section{INTRODUCTION}

The duration and energy consumption required for the thermal treatment to plasticize logs for veneer production depends on the degree of the icing of the log (Chudinov 1966, 1968, Shubin 1990, Požgaj et al. 1997, Trebula - Klement 2002, Videlov 2003, Pervan 2009, Deliiski Dzurenda 2010, Deliiski 2013b).

In the specialized literature, there are limited reports about an experimentally determined or computed temperature distribution of frozen logs subjected to defrosting (Steinhagen 1986, 1991, Steinhagen et al. 1987, Steinhagen - Lee 1988, Khattabi - Steinhagen 1992, 1993, 1995, Deliiski 2004, 2005, 2009, 2011, 2013a, Deliiski - Dzurenda 2010, Deliiski et al. 2014, 2015a,

\footnotetext{
*Corresponding author: deliiski@ netbg.com; 1756 SOFIA, Kliment Ohridski Blvd. 10, Bulgaria
} 
$2015 \mathrm{~b}$ ) and there is no information at all about the experimentally determined temperature distribution in logs during their natural or artificial freezing. That is why the experimental research and the multiparameter study of the freezing process of logs are of considerable scientific and practical interest.

The aim of this work is to suggest a methodology for experimental research of the freezing process of logs and to present the first results from its usage for precise temperature and humidity change measurements of the air processing medium, $t_{\mathrm{m}}$ and $\varphi_{\mathrm{m}}$, respectively. This applies also for measurement of the non-stationary temperature distribution in 4 characteristic points of the longitudinal section of poplar logs during their many hours in a freezer with an adjustable temperature range from $-1{ }^{\circ} \mathrm{C}$ to $-30{ }^{\circ} \mathrm{C}$. An important part of the work is to present and analyze, for the first time ever, the measuring of the experimentally determined impact the latent heat released by the free water on the log had on the warming up of the wood during water crystallization in the logs.

\section{MATERIAL AND METHODS}

The logs subjected to experimental research had a diameter of $240 \mathrm{~mm}$ and a length of $480 \mathrm{~mm}$. They were produced from the sap-wood of freshly-felled poplar trunks (Populus nigra L.) with a diameter of $630 \mathrm{~mm}$ according to a scheme given on Figure 1 (left).

Before the experiments, 4 holes with diameters of $6 \mathrm{~mm}$ and of different lengths were drilled into each $\log$ (Figure 1 - right and Figure 2). Sensors with long cylindrical metal casings were positioned in these 4 holes to measure the temperature of the wood during the experiments. The number of the characteristic points, in which the changes in the wood temperature were measured, was limited by the number of available temperature sensors the automatic system used for the experiments had.
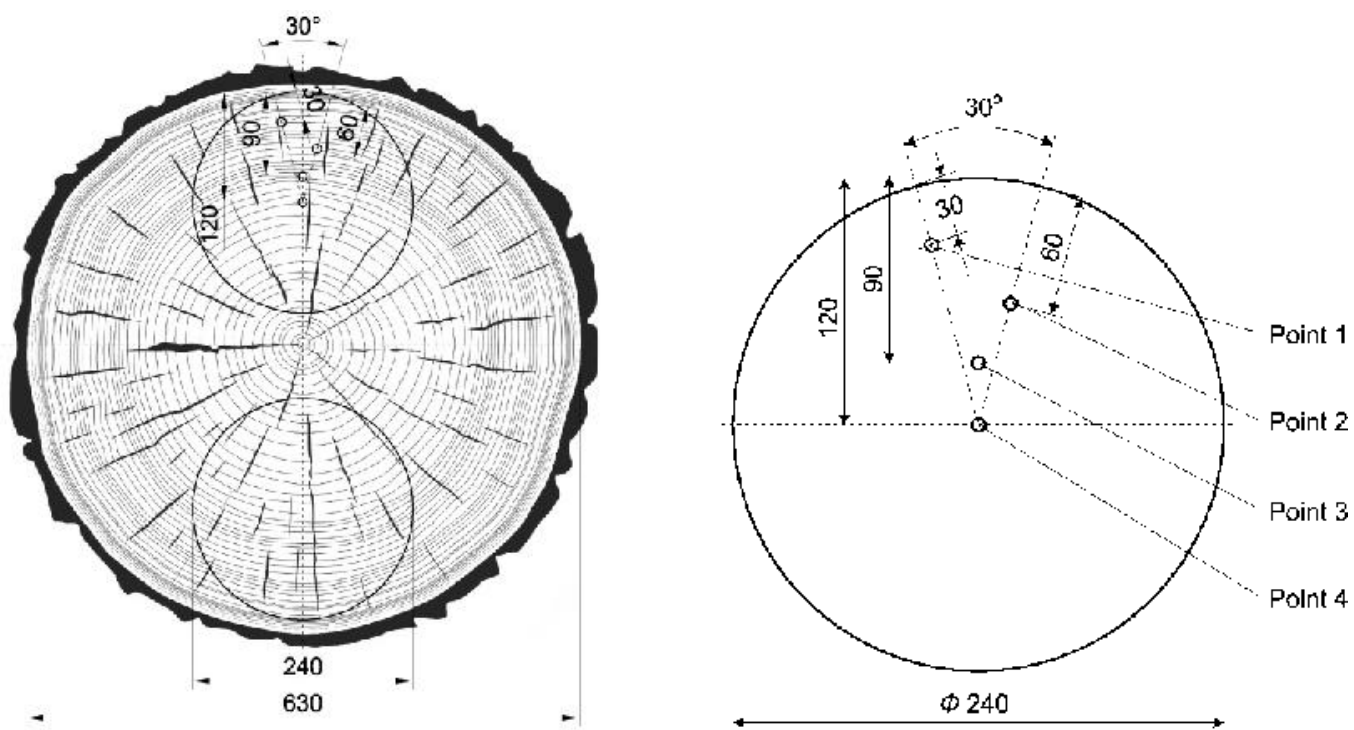

Figure 1. An approach for the production of logs for the experiments (left) and radial coordinates of 4 characteristic points for measurement of the temperature in the logs (right)

The coordinates of the characteristic points of the logs are, as follows:

Point 1: along the $\log$ radius $r=R / 4=30 \mathrm{~mm}$ and along the $\log$ length $z=L / 4=120 \mathrm{~mm}$;

Point 2: along the log radius $r=R / 2=60 \mathrm{~mm}$ and along the log length $z=L / 4=120 \mathrm{~mm}$;

Point 3: along the log radius $r=3 R / 4=90 \mathrm{~mm}$ and along the $\log$ length $z=3 L / 8=180 \mathrm{~mm}$;

Point 4: along the $\log$ radius $r=R=120 \mathrm{~mm}$ and along the $\log$ length $z=L / 2=240 \mathrm{~mm}$. 
These characteristic point coordinates allow for the impact of the heat fluxes to be simultaneously covered in radial and longitudinal directions on the temperature distribution of freezing logs (Figure 2). Point coordinate values that were suitable for temperature computation and visualization in these points were chosen with the help of a 2D model of the freezing process of the logs aimed at its verification (Deliiski et al. 2014).

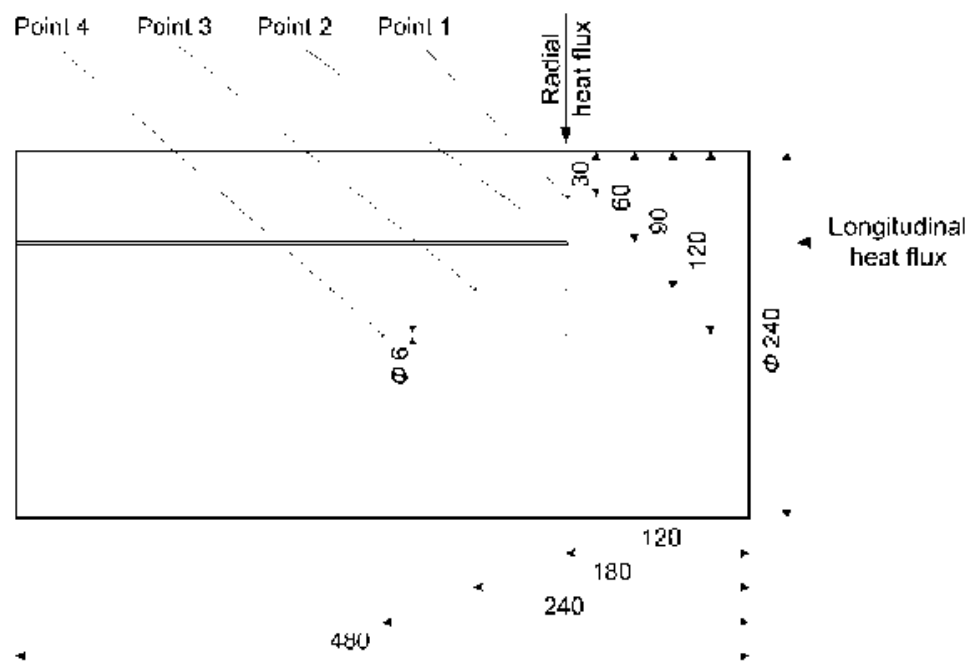

Figure 2. Longitudinal section of log with drilled holes for positioning of sensors for measurement of the wood temperature during the freezing process

Each log prepared for the experiments was placed in a PVC bag with the aim of homogenizing the moisture content in its volume as far as possible. Following this, the experiments began.

To freeze the logs, a horizontal freezer with length of $1.1 \mathrm{~m}$, width of $0.8 \mathrm{~m}$, depth of $0.6 \mathrm{~m}$ and adjustable temperature range from $-1{ }^{\circ} \mathrm{C}$ to $-30{ }^{\circ} \mathrm{C}$ was used (Figure 3 - left).

The automatic measurement and recording of the temperature and humidity of the air processing medium in the freezer as well as of the temperature in the 4 characteristic points in the logs during the experiments was carried out with the help of Data Logger type HygroLog NT3 (Figure 3 - right) produced by the Swiss firm ROTRONIC AG (http:/www.rotronic. com).
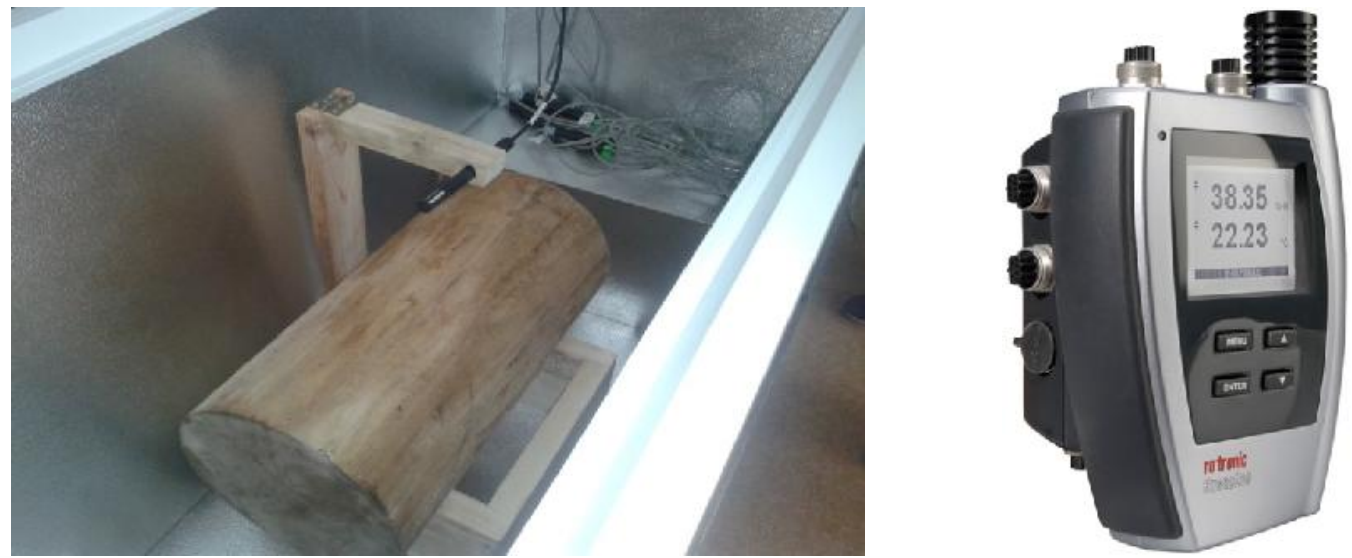

Figure 3. General view of the freezer containing a log (left) and of the Data Logger (right)

The suggested methodology for the research of the freezing process of poplar (Populus nigra L.) $\operatorname{logs}$ with diameter of $D=0.24 \mathrm{~m}$, length of $L=0.48 \mathrm{~m}$, and moisture content above the fiber saturation point was used. Such moisture content allows for the observation of the freezing of both the free and the bound water in the wood during the experiments. 
When the logs were completely frozen, they were subjected to defrosting at room temperature. After that, $35 \mathrm{~mm}$-thick disks from the central, undrilled area of the logs were prepared. According to requirements of the standard BDS ISO 3130: 1999, eleven samples with dimensions of $60 \times 30 \times 35 \mathrm{~mm}$ were made (see Figure 6 below).

The samples were dried at $103 \pm 2{ }^{\circ} \mathrm{C}$ to estimate their initial moisture content $u$ and basic wood density $\rho_{b}$, which is equal to the dry mass divided by the green volume. The average values of $u$ and $\rho_{\mathrm{b}}$ are needed for experimental results analysis and also to solve, modify and verify the mathematical models of the freezing process of the logs (Deliiski et al. 2014, 2015a). The measured results obtained by the Data Logger during the experiments were additionally processed with the help of a personal computer with an installed licensed software, ROTRONIC HW4.

The very precise instrumentation used during the experiments allowed us to detect the latent heat released by the free water and its impact on the wood freezing process during the crystallization of this water (see below). This phenomenon is not well-known or easily comprehensible, hence it will be explained in detail below.

It is common knowledge that when a given substance is subjected to heating, its internal energy and its temperature increase. However, under certain circumstances, the heat deposited in the system is spent performing work without increasing its temperature. This happens when a phase transformation in the substance occurs.

The phase transformation consists in moving from one aggregate state to another - for example, the passing of ice into water. In those cases, the heat introduced in the substance is transformed into work needed for destruction of the bonds between molecules, which are available in the substance before heat introduction. It is acceptable to term this heat as the latent heat of the phase transformation (Efimov 1985, Pahi 2010).

Therefore, the latent heat is used for description of the thermal energy, which is needed for the change of the aggregate state of a given substance without changing its temperature. When the ice is transformed into water, it is acceptable to term this latent heat as latent heat of fusion and when the water turns into steam it is called latent heat of vaporization. It was found that the latent heat of fusion is equal to $3.3410^{5} \mathrm{~J} \mathrm{~kg}^{-1}$ and the latent heat of vaporization is about 6.5 times larger and equal to $2.257210^{6} \mathrm{~J} \mathrm{~kg}^{-1}$ (Chudinov 1966, 1968, Rivkin - Aleksandrov 1975, Efimov 1985, Spears - Zollman 1990, Pahi 2010).

Ice molecules are connected to one another with significant forces of attraction. The kinetic energy of ice molecules increases during heating, which translates into the increase of their amplitude oscillations. When the melting point of the ice is reached, the amplitude of the oscillations increases so much that separate molecules begin to detach from their places and become free. This process is not accompanied by an increase in ice temperature because of the usage of the latent heat introduced for the overcoming of the intermolecular bonds.

The freezing and melting processes of the water in the wood are reversible.

When the water passes into ice during cooling, it releases latent heat in an amount of $3.3410^{5} \mathrm{~J} \mathrm{~kg}^{-1}$. With the help of precise instrumentation, the research and the quantity determination of the impact of the water's latent heat release on the freezing process of the logs are of considerable scientific and practical interest.

\section{RESULTS AND DISCUSSION}

As an example, in Figure 4 and Figure 5, the change in $t_{\mathrm{m}}, \varphi_{\mathrm{m}}$, and $t$ in 4 characteristic points of two poplar logs with different moisture content $u=1.78 \mathrm{~kg} \mathrm{~kg}^{-1}$ and $u=1.04 \mathrm{~kg} \mathrm{~kg}^{-1}$ (named below as Log 1 and $\log 2$ respectively) during their $50 \mathrm{~h}$ freezing is presented. The record of all data was made automatically by Data Logger with intervals of 15 min. 


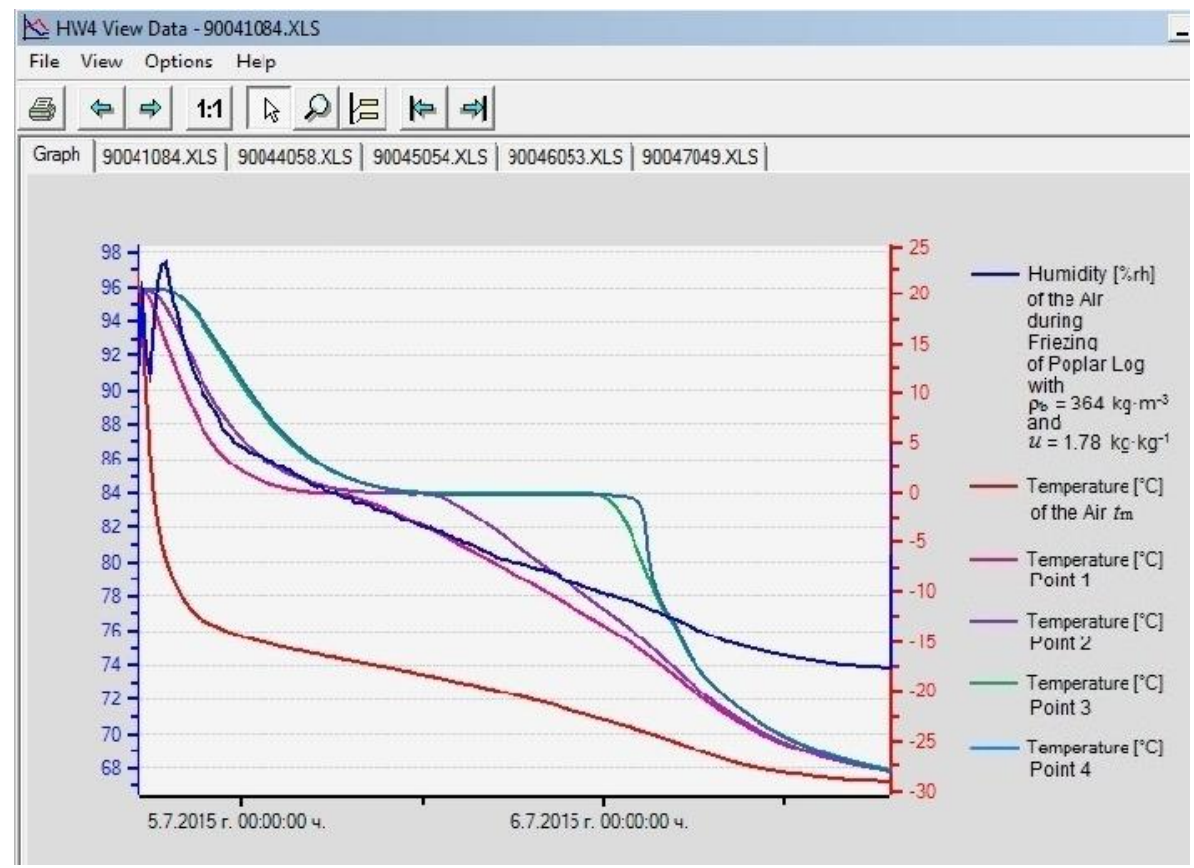

Figure 4. Change in $t_{m}, \varphi_{m}$, and t in 4 characteristic points of poplar Log 1 with $D=0.24 \mathrm{~m}, L=0.48 \mathrm{~m}, t_{0}=20.5^{\circ} \mathrm{C}, \rho_{b}=364 \mathrm{~kg} \mathrm{~m}^{-3}$, and $u=1.78 \mathrm{~kg} \mathrm{~kg}^{-1}$ during its 50 h freezing from 17:00 on 04.07.2015 to 19:00 on 06.07.2015

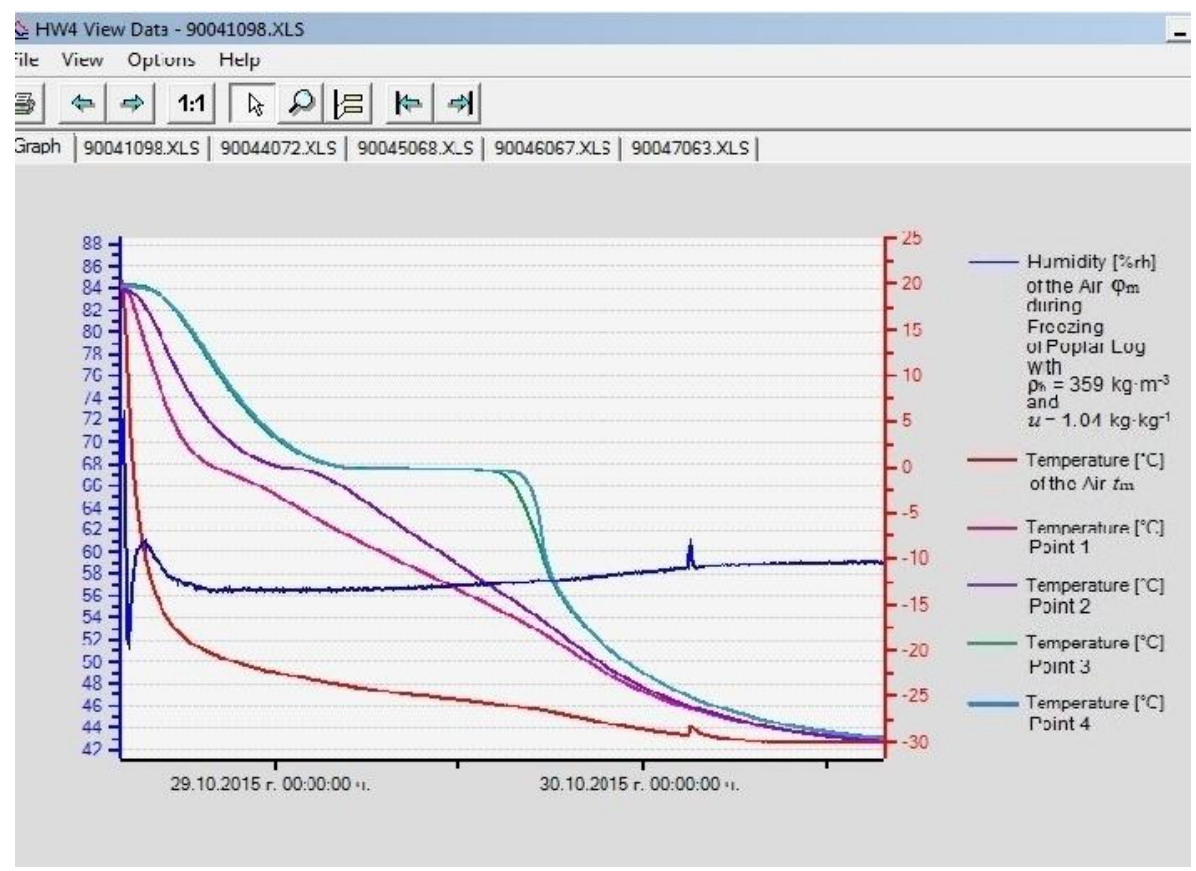

Figure 5. Change in $t_{m}, \varphi_{m}$, and $t$ in 4 characteristic points of poplar Log 2 with $D=0.24 \mathrm{~m}, L=0.48 \mathrm{~m}, t_{0}=19.8^{\circ} \mathrm{C}, \rho_{b}=359 \mathrm{~kg} \mathrm{~m}^{-3}$, and $u=1.04 \mathrm{~kg} \mathrm{~kg}^{-1}$ during its 50 h freezing from 12:00 on 28.10 .2015 to $14: 00$ on 30.10 .2015

In Figure 6 the distribution of the moisture content $u$ and of the basic density $\rho_{b}$ in the cross section of $\log 1$ is shown.

In Figure 7 and Figure 8 the change in $t$ of the separate 4 characteristic points of Log 1 in temperature range from $0{ }^{\circ} \mathrm{C}$ to $-1{ }^{\circ} \mathrm{C}$ is shown. The experiments determined that the freezing of the free water in the wood occurs in this range. 

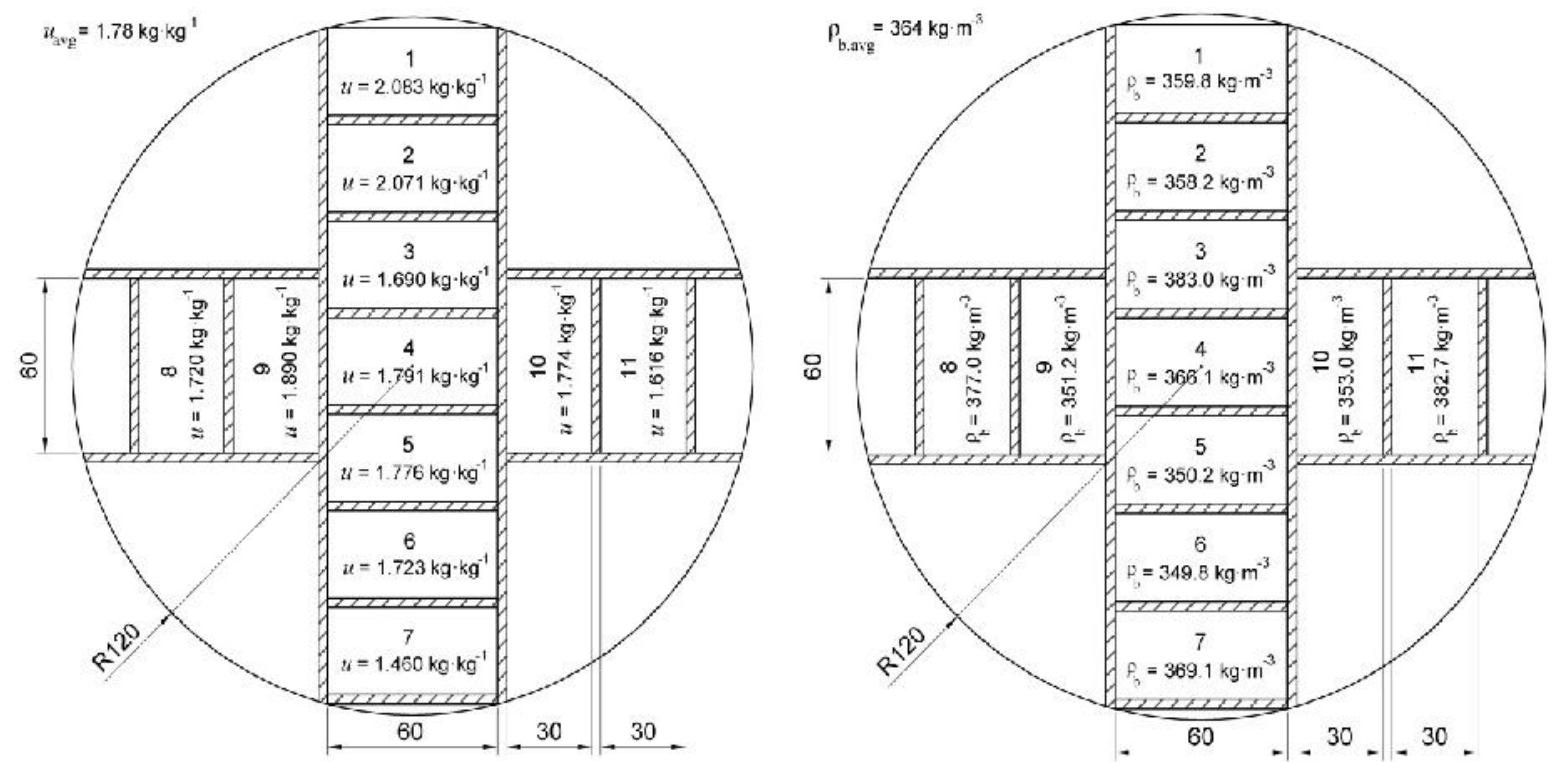

Figure 6. Distribution of $u$ (left) and $\rho_{b}$ (right) in the cross section of Log 1

In Figure 9 and Figure 10 the zoomed change in $t$ in the characteristic points of Log 1 in the temperature ranges is shown, in which the impact of the release of the latent heat of the free water on the increasing of the wood temperature during log freezing is observed.

On the horizontal and vertical axis of Figure 7 to Figure 10 the astronomic time during the experiments and the temperature in ${ }^{\circ} \mathrm{C}$ are presented respectively.
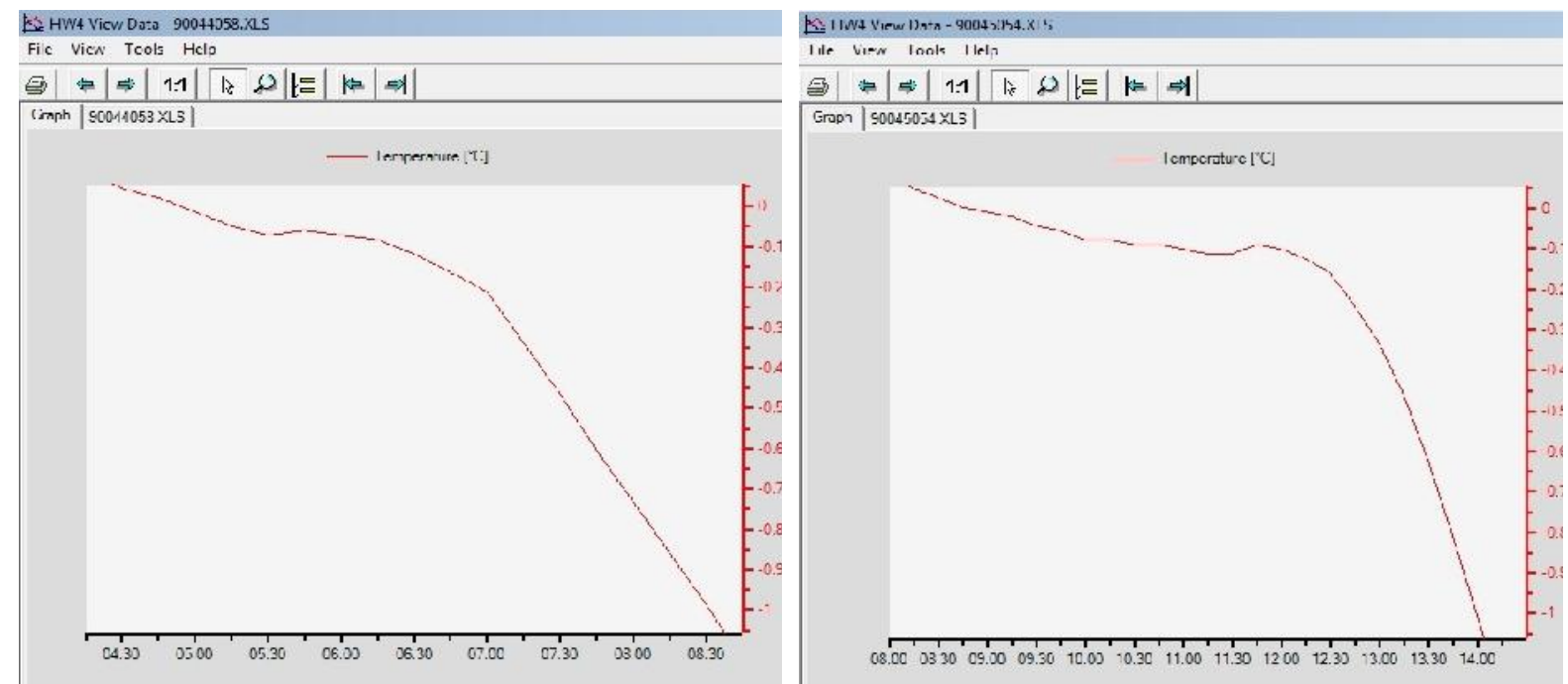

Figure 7. Change in t in Point 1 (left) and in Point 2 (right) of Log 1 in the range from $0{ }^{\circ} \mathrm{C}$ to $-1{ }^{\circ} \mathrm{C}$ during log freezing, depending on time

In Table 1 the duration of the temperature decrease in the characteristic points of $\log 1$ and $\log 2$ in the range from $0{ }^{\circ} \mathrm{C}$ to $-1{ }^{\circ} \mathrm{C}$ is given (see Figure 7 and Figure 8 for Log 1). This duration is needed for its further comparison to the duration of the defrosting process of the same logs in the temperature range from $-1{ }^{\circ} \mathrm{C}$ to $0{ }^{\circ} \mathrm{C}$.

In Table 2 the temperature ranges and the duration of the impact of the latent heat of the free water in the wood on the change in $t$ of the characteristic points in $\log 1$ and $\log 2$ is illustrated. 

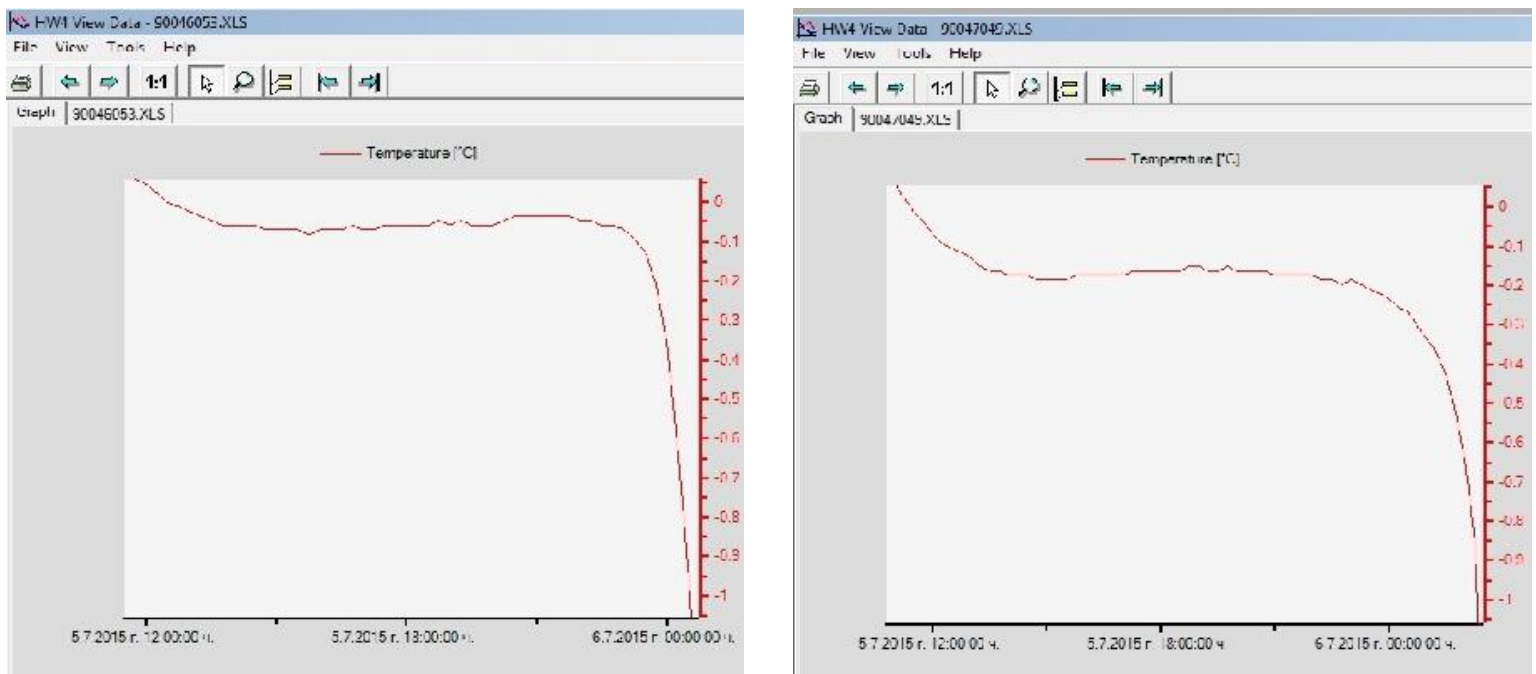

Figure 8. Change in t in Point 3 (left) and in Point 4 (right) of Log 1 in the range from $0{ }^{\circ} \mathrm{C}$ to $-1{ }^{\circ} \mathrm{C}$ during log freezing, depending on time
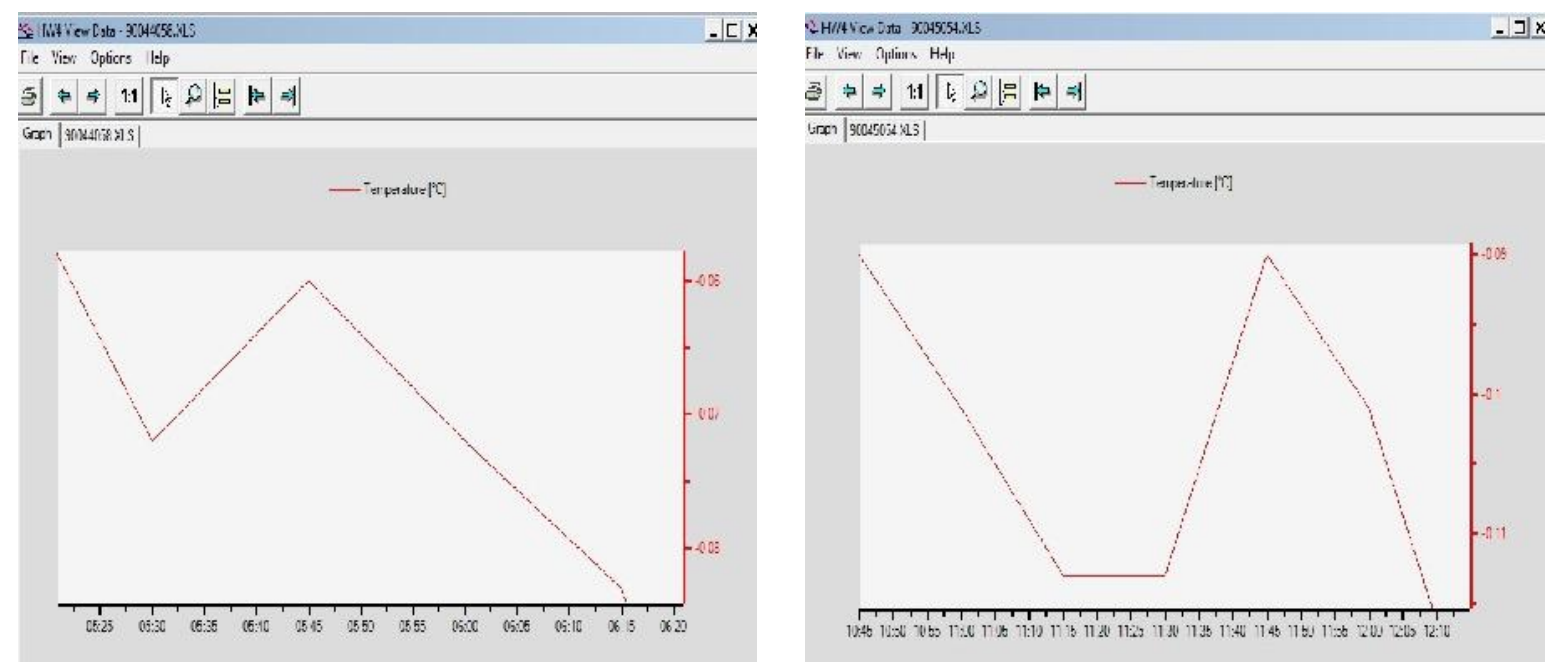

Figure 9. Change in t in Point 1 (left) and in Point 2 (right) of Log 1 during the impact of the release of the latent heat of the free water on the log freezing process
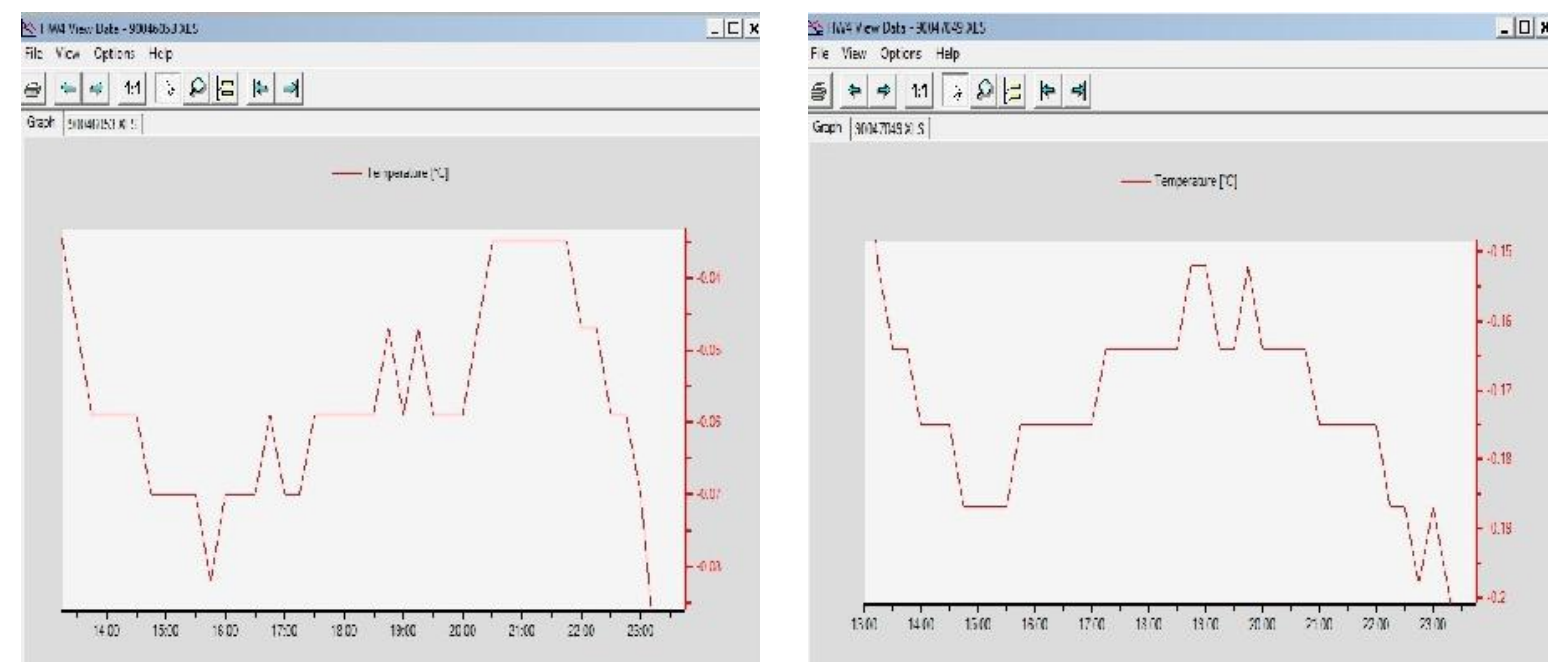

Figure 10. Change in t in Point 3 (left) and in Point 4 (right) of Log 1 during the impact of the release of the latent heat of the free water on the log freezing process 
Table 1. Duration of the decreasing of $t$ from $0{ }^{\circ} \mathrm{C}$ to $-1{ }^{\circ} \mathrm{C}$ in the characteristic points of poplar logs during their 50 hreezing

\begin{tabular}{|c|c|c|c|}
\hline \multirow{2}{*}{ № } & \multicolumn{2}{|c|}{ Time of reaching of temperature equal to } & \multirow{2}{*}{$\begin{array}{l}\text { Duration of the decreasing } \\
\text { of } t \text { from } 0^{\circ} \mathrm{C} \text { to }-1{ }^{\circ} \mathrm{C}, \mathrm{h}\end{array}$} \\
\hline & $0{ }^{\circ} \mathrm{C}$ & $-1{ }^{\circ} \mathrm{C}$ & \\
\hline \multicolumn{4}{|c|}{ Log 1 with $t_{0}=20.5^{\circ} \mathrm{C}, \rho_{\mathrm{b}}=364 \mathrm{~kg} \mathrm{~m}^{-3}$, and $u=1.78 \mathrm{~kg} \mathrm{~kg}^{-1}$} \\
\hline Point 1 & $4: 54$ on 05.07 .2015 & $8: 32$ on 05.07 .2015 & 3.63 \\
\hline Point 2 & $8: 49$ on 05.07 .2015 & $14: 00$ on 05.07 .2015 & 5.18 \\
\hline Point 3 & $12: 30$ on 05.07 .2015 & $0: 32$ on 06.07 .2015 & 12.03 \\
\hline Point 4 & $11: 24$ on 05.07 .2015 & $2: 19$ on 06.07 .2015 & 14.92 \\
\hline \multicolumn{4}{|c|}{ Log 2 with $t_{0}=19.8^{\circ} \mathrm{C}, \rho_{\mathrm{b}}=359 \mathrm{~kg} \mathrm{~m}^{-3}$, and $u=1.04 \mathrm{~kg} \mathrm{~kg}^{-1}$} \\
\hline Point 1 & $20: 07$ on 28.10 .2015 & $21: 34$ on 28.10 .2015 & 1.45 \\
\hline Point 2 & $0: 31$ on 29.10 .2015 & $3: 14$ on 29.10 .2015 & 2.72 \\
\hline Point 3 & $4: 45$ on 29.10 .2015 & $15: 07$ on 29.10 .2015 & 10.37 \\
\hline Point 4 & 4.40 on 29.10 .2015 & $16: 10$ on 29.10 .2015 & 11.50 \\
\hline
\end{tabular}

Table 2. Duration $\tau_{L H}$ and temperature difference $t_{L H}$ of the impact of the latent heat $(L H)$ of the free water on the increasing of the wood temperature in the characteristic points of poplar logs during their $50 \mathrm{~h}$ freezing

\begin{tabular}{|c|c|c|c|c|c|c|}
\hline \multirow[t]{2}{*}{ № } & \multicolumn{2}{|c|}{$\begin{array}{l}\text { Time and wood temperature at } \\
\text { the beginning and ending of } \\
\text { the impact of } \mathrm{LH} \text { on the wood } \\
\text { freezing }\end{array}$} & \multicolumn{2}{|c|}{$\begin{array}{l}\text { Maximal wood temperature } \\
\text { and time of its reaching under } \\
\text { impact of LH on the wood } \\
\text { freezing }\end{array}$} & \multirow{2}{*}{$\begin{array}{c}\tau_{\mathrm{LH}} \\
\mathrm{h}\end{array}$} & \multirow{2}{*}{$\begin{array}{l}t_{\mathrm{LH}}, \\
{ }^{\circ} \mathrm{C}\end{array}$} \\
\hline & Time & $t_{\mathrm{LH}}^{\mathrm{beg}},{ }^{\circ} \mathrm{C}$ & $t_{\mathrm{LH}}^{\max },{ }^{\circ} \mathrm{C}$ & Time & & \\
\hline \multicolumn{7}{|c|}{ Log 1 with $t_{0}=20.5^{\circ} \mathrm{C}, \rho_{\mathrm{b}}=364 \mathrm{~kg} \mathrm{~m}^{-3}$, and $u=1.78 \mathrm{~kg} \mathrm{~kg}^{-1}$} \\
\hline Point 1 & $5: 30$ and $6: 00$ & -0.072 & -0.060 & $5: 45$ & 0.50 & 0.012 \\
\hline Point 2 & $11: 15$ and $12: 07$ & -0.113 & -0.090 & $11: 45$ & 0.87 & 0.023 \\
\hline Point 3 & $15: 45$ and $22: 45$ & -0.082 & -0.035 & $20: 30$ & 7.00 & 0.047 \\
\hline Point 4 & $14: 45$ and $23: 00$ & -0.187 & -0.152 & $18: 45$ & 8.25 & 0.035 \\
\hline \multicolumn{7}{|c|}{ Log 2 with $t_{0}=19.8^{\circ} \mathrm{C}, \rho_{\mathrm{b}}=359 \mathrm{~kg} \mathrm{~m}^{-3}$, and $u=1.04 \mathrm{~kg} \mathrm{~kg}^{-1}$} \\
\hline Point 1 & $20: 15$ and $20: 30$ & -0.120 & -0.120 & $20: 15$ & 0.25 & 0.093 \\
\hline Point 2 & $1: 10$ and $1: 30$ & -0.110 & -0.110 & $1: 10$ & 0.33 & 0.070 \\
\hline Point 3 & 5:05 and $7: 24$ & -0.059 & -0.001 & $5: 30$ & 2.32 & 0.058 \\
\hline Point 4 & $5: 40$ and $10: 20$ & -0.164 & -0.036 & $6: 15$ & 4.70 & 0.128 \\
\hline
\end{tabular}

The experimental results presented above, and also the results from our research of the freezing process of logs from some wood species (poplar, beech, pine, and spruce) at different moisture contents, show that the free water in the wood freezes in the temperature range between $0{ }^{\circ} \mathrm{C}$ and $-1{ }^{\circ} \mathrm{C}$. This fact did not prove the points of view of Chudinov $(1966,1968)$ and Topgaard - Söderman (2002), which have been presented in Deliiski et al. (2015c). According to these scientists, if the wood has a significant quantity of free water, i.e. if the cell holes and the gaps among the cells are almost completely filled with water (such a condition was fulfilled in our experiments presented above), the centers of crystallization during cooling arise in the water at temperatures around $-5{ }^{\circ} \mathrm{C} \div-6^{\circ}$. According to the same authors, if the wood moisture content is slightly larger than the fiber saturation point, i.e. a small quantity of free water is present in the wood, then the centers of crystallization in it arise even at temperatures around $-12{ }^{\circ} \mathrm{C} \div-15^{\circ}$.

The analysis of the obtained results about the freezing process of the studied logs showed the following: 
- The temperature decrease of the processing air medium $t_{\mathrm{m}}$ in the freezer goes on exponentially at the beginning of the freezing process of the logs and, after that, gradually passes into an almost straight line (Figure 4 and Figure 5).

- The change of the humidity of the processing air medium $\varphi_{\mathrm{m}}$ in the freezer goes on according to a complex curve. At the beginning of the freezing process it jumps up to 97\% at Log 1 (Figure 4) and up to $73 \%$ at Log 2 (Figure 5), but after that it gradually decreases smoothly and reaches a value of $74 \%(\log 1)$ and of $59 \%(\log 2)$ at the end of the $50 \mathrm{~h}$ logs' freezing.

- The non-stationary decreasing of the temperature in the logs' characteristic points goes on according to very complex curves during the freezing process (Figure 4 and Figure 5).

- While the water in the $\log$ is fully in a liquid state, the decreasing of $t_{\mathrm{m}}$ causes a smooth decreasing of $\mathrm{t}$ in the characteristic points. The smoothness of the decreasing of $t$ depends proportionally on the distance of the points from both logs' surfaces.

- Specific, almost horizontal sections of temperature retention for a long period of time in the range from $0{ }^{\circ} \mathrm{C}$ to $-1{ }^{\circ} \mathrm{C}$ can be seen, while in the points a complete freezing of the free water in the wood occurs (Figure 7 and Figure 8). How far the point is distanced from the logs' surfaces and the larger the amount of the free water in the wood determines how much these sections with temperature retention are extended, as follows (Table 1):

- in Point 1: $3.63 \mathrm{~h}$ for $\log 1$ and $\quad 1.45 \mathrm{~h}$ for $\log 2$;

- in Point 2: $5.18 \mathrm{~h}$ for $\log 1$ and $\quad 2.72 \mathrm{~h}$ for $\log 2$;

- in Point 3: $12.03 \mathrm{~h}$ for $\log 1$ and $10.37 \mathrm{~h}$ for $\log 2$;

- in Point 4: $14.92 \mathrm{~h}$ for $\log 1$ and $11.50 \mathrm{~h}$ for $\log 2$.

The reason of such a long retention of wood temperature is the very low temperature conductivity of the wood during freezing of the free water in it (Deliiski et al. 2015b). It is seen in Table 1 that the temperature $t$ in Point 4, which is the most distanced from the logs' surfaces, reaches a value of $0{ }^{\circ} \mathrm{C}$ earlier than $t$ in Point 3 during the initial cooling of logs before their subsequent freezing. This apparent anomaly can be explained by the influence of the smaller moisture content $u$ of the bottom part of the logs (in comparison with the moisture content of their upper parts) on the wood temperature conductivity, $a$. For example, the average value of $u$ for the bottom layers 5,6 , and 7 of Log 1 (Figure 6 - left) is equal to $1.653 \mathrm{~kg} \mathrm{~kg}^{-1}$; however, the average value of $u$ for the upper layers 1,2 , and 3 is equal to $1.948 \mathrm{~kg} \mathrm{~kg}^{-1}$ i.e. it is larger by about $18 \%$.

The coordinates of Point 3 determine that the change of $t$ in this point depends on the heat transfer only through the upper log's layers (Figure 1 - right and Figure 2), but the change in $t$ of central log's Point 4 depends on the heat transfer through all the log's layers.

It is well known that the decrease in $u$ of the non-frozen wood causes an increase in its temperature conductivity a (Chudinov 1966, 1968, Shubin 1990, Požgaj et al. 1997, Trebula - Klement 2002, Videlov 2003, Deliiski 2013b, Deliiski et al. 2015b). In our case, this means that the lower moisture content of the bottom logs' layers causes an accelerated heat transfer in radial direction to Point 4 in comparison to the heat transfer to Point 3. As a consequence, the temperature of $0{ }^{\circ} \mathrm{C}$ is reached earlier in Point 4 than in Point 3 during the log's cooling, which is an initial part of the logs' freezing process. The difference between the average moisture contents of the bottom and upper (wetter) layers of $\log 2$ is significantly less than of $\log 1$. That is why reaching $0{ }^{\circ} \mathrm{C}$ in Point 4 of $\log 2$ occurs only 5 min earlier than in Point 3 while Point 4 of $\log 1$ reaches $0{ }^{\circ} \mathrm{C}$ 60 min earlier than Point 3 (refer to Table 1). 
- During the freezing of the free water in the log, specific sections of insignificant increases in wood temperature arise (Figure 9 and Figure 10). The reason for this is the impact of the latent heat of the free water, which is released during water crystallization and causes the warming up of the wood (Efimov 1985, Spears - Zollman 1990, Pahi 2010). The increase of the wood temperature, $t_{\mathrm{LH}}$, which is caused by the released latent heat, for poplar Log 1 with moisture content $u=1.78 \mathrm{~kg} \mathrm{~kg}^{-1}$ was measured to be equal between $0.012{ }^{\circ} \mathrm{C}$ and $0.047^{\circ} \mathrm{C}$. The duration of the warming up of the wood because of the latent heat release, $\tau_{\mathrm{LH}}$, was equal to $0.50 \mathrm{~h}$ for Point $1 ; 0.87 \mathrm{~h}$ for Point $2 ; 7.00 \mathrm{~h}$ for Point 3 and $8.25 \mathrm{~h}$ for Point 4 (Table 2).

Analogously, the temperature increase $t_{\mathrm{LH}}$ for poplar $\log 2$ with lower moisture content $u=1.04 \mathrm{~kg} \mathrm{~kg}^{-1}$ was measured to be equal between $0.058{ }^{\circ} \mathrm{C}$ and $0.128^{\circ} \mathrm{C}$. The duration $\tau_{\mathrm{LH}}$ for this $\log$ was equal to $0.25 \mathrm{~h}$ for Point $1 ; 0.33 \mathrm{~h}$ for Point $2 ; 2.32 \mathrm{~h}$ for Point 3, and $4.70 \mathrm{~h}$ for Point 4.

It can be noted that if the temperature data recording by Data Logger had been performed with intervals shorter than $15 \mathrm{~min}$, the maximum wood temperature, $t_{\mathrm{LH}}^{\max }$, and time of its reaching under impact of LH on wood freezing would be different than these given in Table 2; thus, the values of $t_{\mathrm{LH}}$ for $\log 1$ probably would be larger than the values of $t_{\mathrm{LH}}$ for $\log 2$.

- After the whole amount of free water in the separate characteristic point freezes, the bound water in the wood starts to freeze. The decreasing of $t$ in all points during the freezing of the bound water is smoother than the decreasing of $t$ during the cooling of the logs before the starting of the water crystallization in the wood.

When the $50 \mathrm{~h}$ freezing process ends, the temperature of all characteristic points of $\mathrm{Log}$ 1 and $\log 2$ reach a value equal to $-27.9 \pm 0.2^{\circ} \mathrm{C}$ and $-29.6 \pm 0.1{ }^{\circ} \mathrm{C}$ respectively. Then the temperature $t_{\mathrm{m}}$ is equal to $-29.1{ }^{\circ} \mathrm{C}$ and $-30.1{ }^{\circ} \mathrm{C}$ respectively (see Figure 4 and Figure 5).

\section{CONCLUSIONS}

This paper describes a methodology for experimental research of the freezing process of logs. It also presents the first results from the usage of the suggested methodology for measurement of the change in the temperature and humidity of the processing medium, $t_{\mathrm{m}}$ and $\varphi_{\mathrm{m}}$, respectively, and also in the non-stationary temperature distribution in 4 characteristic points of the longitudinal section of poplar logs during their 50 hours freezing in a freezer with an adjustable temperature range from $-1{ }^{\circ} \mathrm{C}$ to $-30^{\circ} \mathrm{C}$.

The precise instrumentation allowed, for the first time ever, the measuring of the impact the latent heat released by the free water on the log had on the warming up of the wood during water crystallization in the logs. The increase of the wood temperature caused by the released latent heat, for the studied poplar logs with moisture content $u=1.78 \mathrm{~kg} \mathrm{~kg}^{-1}$ (Log 1) and $u=1.04 \mathrm{~kg} \mathrm{~kg}^{-1}(\log 2)$ was measured to be equal between $0.012{ }^{\circ} \mathrm{C}$ and $0.047{ }^{\circ} \mathrm{C}$ for $\log 1$ and between $0.058{ }^{\circ} \mathrm{C}$ and $0.128{ }^{\circ} \mathrm{C}$ for $\log 2$. The impact of the latent heat release on the wood's warming up lasts from $0.50 \mathrm{~h}$ in the peripheral layers of the $\log 1$ to $8.25 \mathrm{~h}$ in the log's center and from $0.25 \mathrm{~h}$ to $4.70 \mathrm{~h}$ for $\log 2$.

It can be noted that in the accessible specialized literature, there is no information at all about the impact of the release of the latent heat on the wood freezing process.

Our experimental results show that the free water in the wood freezes in a temperature range between $0{ }^{\circ} \mathrm{C}$ and $-1{ }^{\circ} \mathrm{C}$. This fact did not prove the points of view of some of the above mentioned authors who claim the free water in the wood freezes at much lower temperatures. 
Our results prove the popular belief that after the whole amount of free water freezes, the freezing of the bound water in the wood starts and that it takes place gradually during the rest time of the experiments.

The obtained experimental results will be used for the modification and verification of our 1D and 2D mathematical models of the freezing process of logs (Deliiski et al. 2014, 2015a). They could be very useful for the creation, solution, and verification of analogous models by other researchers.

The methodology suggested in this work could be used for experimental research of the freezing processes of different capillary-porous bodies. For example, for winter research concerning the impact of free water in live trees or in fresh concrete regarding freezing along the radius or the thickness at different ambient temperatures, etc.

\section{REFERENCES}

Chudinov, B. S. (1966): Teoreticheskie issledovania teplofizicheskih svoystv i teplovoy obrabotki dreveciny. [Theoretical Research of Thermo-Physical Properties and Thermal Treatment of Wood]. Dissertation for DSc., SibLTI, Krasnoyarsk, USSR (in Russian)

Chudinov, B. S. (1968): Teoria teplovoy obrabotki drevesiny [Theory of Thermal Treatment of Wood]. Nauka, Moscow, USSR, 255 p. (in Russian)

DeliISKI, N. (2004): Modelling and Automatic Control of Heat Energy Consumption Required for Thermal Treatment of Logs. Drvna Industrija, 55 (4): 181-199.

DeliISKI, N. (2005) Modeling and Automatic Control of the Process of Thermal Treatment of Logs. Information Technologies and Control, UAI, Sofia, 3 (2): 9-14.

DELIISKI, N. (2009): Computation of the 2-dimensional Transient Temperature Distribution and Heat Energy Consumption of Frozen and Non-Frozen Logs. Wood Research, 54 (3): 67-78.

DeliISKI, N. (2011): Transient Heat Conduction in Capillary Porous Bodies. In Ahsan A. (ed) Convection and Conduction Heat Transfer. InTech Publishing House, Rieka: 149-176, http://dx.doi.org/ 10.5772/21424

DELIISKI, N. (2013a): Computation of the Wood Thermal Conductivity during Defrosting of the Wood. Wood research, 58 (4): 637-650.

DELIISKI, N. (2013b): Modelling of the Energy Needed for Heating of Capillary Porous Bodies in Frozen and Non-Frozen States. Lambert Academic Publishing, Scholars' Press, Saarbrücken, Germany, 116 p., http://www. scholars-press.com//system/covergenerator/build/1060

DELIISKI, N., DZURENDA, L. (2010): Modelling of the thermal processes in the technologies for wood thermal treatment. TU Zvolen, Slovakia, 224 p. (in Russian)

DELIISKI, N. - BREZIN, V. - TUMBARKOVA, N. (2014): Modelling of the 2D convective heat exchange between subjected to freezing and to following defrosting logs and the surrounding environment. Annals of Warsaw University of Life Sciences, Forestry and Wood Technology, 86: 67-75.

DELIISKI, N. - BREZIN, V. - TUMBARKOVA, N. (2015a): Modelling of the 1D Convective Heat Exchange Between Logs Subjected to Freezing and to Subsequent Defrosting and the Surrounding Environment. Acta Silvatica et Lignaria Hungarica, 11 (1): 77-88, DOI: 10.1515/aslh-2015-0001 http://aslh.nyme.hu/fileadmin/dokumentumok/fmk/acta_silvatica/cikkek/Vol112015/06_deliiski_et_al.pdf

Deliski, N. - DZuRENDA, L. - Tumbarkova, N. - ANGelski, D. (2015b): Computation of the Temperature Conductivity of Frozen Wood During its Defrosting. Drvna Industrija, 66 (2): 87-96, http://hrcak.srce/hr/index/php?show=clanak\&id_clanak_jezik=207489 doi: 105552/drind. 2015/1351

DELIISKI, N. - TUMBARKOVA, N. - DZURENDA, L. - BREZIN, V. (2015c): Computation of the wood thermal conductivity above the hygroscopic range during freezing of the wood. Acta Facultatis Xilologiae, TU-Zvolen, 57 (2): 27-37, ISSN 1336-3824, DOI: 10.17423/afx.2015.57.2.03. 
EFIMOV, S. N. (1985): Temperaturnaya zavisimost tepla kristallizacii vody [Temperature Dependence of the Heat of Water Crystallization]. Engineering-Physical Journal of the Institute of PhysicTechnical Problems of the Nord, Siberian Department of the Academy of Sciences of USSR, Yakutsk, 49 (4): 658-664 (in Russian)

Khattabi, A. - Steinhagen, H. P. (1992): Numerical Solution to Two-dimensional Heating of Logs. Holz als Roh- und Werkstoff, 50 (7-8): 308-312, http://dx.doi.org/10.1007/ BF02615359

Khattabi, A. - Steinhagen, H. P. (1993): Analysis of Transient Non-linear Heat Conduction in Wood Using Finite-difference Solutions. Holz als Roh- und Werkstoff, 51(4): 272-278, http://dx.doi.org/10.1007/ BF02629373

Khattabi, A. - Steinhagen, H. P. (1995): Update of "Numerical Solution to Two-dimensional Heating of Logs". Holz als Roh- und Werkstoff, 53(1): 93-94, http://dx.doi.org/10.1007/ BF02716399

PERVAN, S. (2009): Technology for Treatment of Wood with Water Steam. University in Zagreb (in Croatian)

PAHI, S. (2010): Understanding Specific Latent Heat. Lesson 4.3 - Understanding Thermal Latent Heat. Bidang sains dan matematik. https://keterehsky.files.wordpress.com/.../ lesson-4.3-understanding-ther

PoŽGAJ, A. - ChOVANEC, D. - KURJATKO, S. - BABIAK, M. (1997): Štruktúra a vlastnosti dreva [Structure and properties of wood]. $2^{\text {nd }}$ edition, Priroda a.s., Bratislava, 485 p. (in Slovak)

RIVKIN, S. L. - ALEKSANDROV, . . . (1975): Termodinamicheskie svoystva vody i vodyanogo para [Thermodynamic Properties of Water and Water Steam]. Energia, Moskow, 85 p. (in Russian)

SHUBIN, G. S. (1990): Sushka i teplovaya obrabotka drevesiny [Drying and Thermal Treatment of Wood]. Lesnaya Promyshlennost, Moskow, URSS, 337 p. (in Russian)

Spears, J. - Zollman, D. (1990): Fascination of Physics. Chapter 10: Thermal Energy in Matter. Benjamin/Cummings Publishing Co., 221-224, https://web.phys.ksu.edu/fascination/contents. html

Steinhagen, H. P. (1986): Computerized Finite-difference Method to Calculate Transient Heat Conduction with Thawing. Wood Fiber Science, 18 (3): 460-467.

Steinhagen, H. P. (1991): Heat Transfer Computation for a Long, Frozen Log Heated in Agitated Water or Steam - A Practical Recipe. Holz als Roh- und Werkstoff, 49 (7-8): 287-290, http://dx.doi.org/10.1007/ BF02663790

Steinhagen, H. P. - LeE, H. W. (1988): Enthalpy Method to Compute Radial Heating and Thawing of Logs. Wood Fiber Science, 20 (4): 415-421.

Steinhagen, H. P. - LeE, H. P. - LOEHNERTZ, S. P. (1987): LOGHEAT: A Computer Program of Determining Log Heating Times for Frozen and Non-Frozen Logs. Forest Products Journal, 37 (11-12): 60-64.

TOPGAARD, D. - SÖDERMAN, O. (2002): Self-diffusion of nonfreezing water in porous carbohydrate polymer systems studied with nuclear magnetic resonance. Biophysical J. 83: 3596-3606.

Trebula, P. - Klement, I. (2002): Drying and Hydro-thermal Treatment of Wood. Technical University in Zvolen, Slovakia, 449 p. (in Slovak)

VIDELOV, CH. (2003): Sushene i toplinno obrabotvane na darvesinata [Drying and Thermal Treatment of Wood]. University of Forestry in Sofia, Sofia, 335 p. (in Bulgarian)

http:/www.rotronic.com/humidity-measurement-feuchtemessung-temperaturmessung-dataloggers-datenlogger/hygrolog-hl-nt3.html 